\title{
Frequency and characteristics of selected enteropathogens in fecal and rectal specimens from childhood diarrhea in Trinidad, 1998-2000
}

\author{
Zobida Khan-Mohammed, ${ }^{1}$ Abiodun A. Adesiyun, ${ }^{2}$ \\ William H. Swanston, ${ }^{2}$ and Dave D. Chadee ${ }^{3}$
}

Suggested citiation: Khan-Mohammed Z, Adesiyun AA, Swanston W, Chadee D. Frequency and characteristics of selected enteropathogens in fecal and rectal specimens from childhood diarrhea in Trinidad, 1998-2000. Rev Panam Salud Publica. 2005;17(3):170-7.

ABSTRACT Objective. To determine the prevalence and characteristics of selected enteric pathogens in diarrheic children in six counties of the island of Trinidad.

Methods. This cross-sectional study was conducted from April 1998 through March 2000. Fecal or rectal swab specimens from children ( $<12$ years) were collected and then processed, using standard methods, to detect Salmonella spp., Shigella spp., enteropathogenic Escherichia coli (EPEC), Campylobacter spp., Yersinia spp., Cryptosporidium parvum, and parasite ova. The antibiograms of the enteropathogens were determined using the disk diffusion method.

Results. A total of 236 samples were processed; 86 samples originated directly from 17 heath centers in two counties (St. George East and St. George West), while 150 samples were obtained from the Trinidad Public Health Laboratory, having been submitted by private practitioners and personnel from six counties in Trinidad. Of the 236 samples, 33 (14.0\%) were positive for Shigella, 4 (1.7\%) for Salmonella, and $1(0.4 \%)$ for EPEC. Two of the samples $(0.8 \%)$ were positive for Campylobacter jejuni, while 1 sample $(0.4 \%)$ was positive for hookworm ova. All the samples were negative for Cryptosporidium parvum and Yersinia spp. With the 86 samples collected directly from the health centers, in St. George East County the frequency of Shigella was 20.0\% (12 of 60), compared with $26.9 \%$ (7 of 26) for samples from St. George West County, but the difference was not statistically significant $(\mathrm{P}>0.05$ with the chi-square test). For the 150 samples from the six counties that had been submitted directly to the Trinidad Public Health Laboratory, 14 of them (9.3\%) were positive for Shigella, a figure statistically significantly lower than that found with the samples sampled directly from the health centers $(\mathrm{P}<0.05$ with the chi-square test). Sh. sonnei was the predominant serotype detected, accounting for 28 of the 33 Shigella isolates (84.8\%) recovered from the 236 samples. Overall, the frequency of detection of enteropathogens had no seasonal pattern nor relationship to the county of origin. Of the 37 isolates of Salmonella and Shigella tested for antimicrobial sensitivity, all of them were sensitive to ciprofloxacin, gentamicin, and cefotaxime.

1 Trinidad and Tobago, Public Health Laboratory, Federation Park, Port-of-Spain, Trinidad and Tobago.

2 University of the West Indies, Faculty of Medical Sciences, St. Augustine, Trinidad and Tobago.
Send correspondence to: Professor A. A. Adesiyun, School of Veterinary Medicine, Faculty of Medical Sciences, University of the West Indies, St. Augustine, Trinidad and Tobago; e-mail: abiodunadesiyun@hotmail.com

\footnotetext{
University of the West Indies, Faculty of Science and Agriculture, Department of Life Sciences, St. Augustine, Trinidad and Tobago, and Ministry of Health, St. Joseph, Trinidad and Tobago.
} 
In terms of resistance, 3 of the 37 isolates (8.1\%) exhibited resistance to ampicillin, 1 (2.7\%) to chloramphenicol, and $1(2.7 \%)$ to sulfamethoxazole/ trimethoprim.

Conclusion. Of the enteropathogens for which assays were done, Shigella sonnei was the most prevalent, and it has the highest probability of being an important etiological agent of childhood diarrhea in Trinidad.

Key words Diarrhea; bacterial infections; drug resistance, microbial; Trinidad and Tobago.

Over the period of 1965 to 1990, mortality due to intestinal infectious diseases declined noticeably in Latin America and the Caribbean. Nevertheless, the mortality rate from those diseases still ranged from 0.17 to 9.83 per 1000 inhabitants for the 1985-1990 period (1). In the Caribbean countries in 1979 , the death rate from diarrheal diseases was 103.8 per 100000 among children under 5 years of age (2), while in Trinidad and Tobago, enteritis and diarrheal diseases were the second most common causes of death in children under 1 year of age $(3,4)$. The most recent available data on Trinidad and Tobago indicated that in 1999 the mortality rate from intestinal infectious diseases among children less than 14 years old was 2.8 per 100000 , while the crude death rate from all causes for all age groups was 800 per 100000 (5). The only reported comprehensive study on childhood diarrhea on the island of Trinidad (2) was hospital-based, and rotavirus was implicated as the most important etiologic agent for gastroenteritis. However, the prevalence and epidemiology of diarrheal agents among persons who visit health centers and private practitioners across Trinidad and Tobago may be different from that of hospitalized patients.

In recent years, Escherichia coli O157:H7 strains have attained importance, causing gastroenteritis in humans who have consumed foods of animal origin, with multistate epidemics reported in the United States of America (6). The relative importance of this serotype of E. coli in the epidemiology of human gastroenteritis in Trinidad is presently unknown. To date, however, cow's milk and some ready-to-eat foods, including black pudding ("boudin noir," a local delicacy made from cooked pig's or cattle's small intestine stuffed with clotted blood, seasoning, and bread crumbs), were reported to be contaminated by this serotype of E. coli $(7,8)$.

Of zoonotic importance in Trinidad was the reported association between human salmonellosis and isolation of Salmonella in livestock and in pet dogs $(9,10)$. There has been a phenomenal rise in the number of Salmonella enterica serovar Enteritidis ( $S$. Enteritidis) strains isolated from various sources (humans, foods, and animals) in Trinidad and elsewhere in the Caribbean from 1992 to date (Caribbean Epidemiology Center, personal communication). Adesiyun et al. (11) recently used pulsed field gel electrophoresis to characterize $S$. Enteritidis from Trinidad and Tobago and elsewhere in the Caribbean. The extent of involvement of this serotype of Salmonella in childhood diarrhea at the community level in Trinidad is presently unknown.

Cryptosporidium paroum has been detected in the feces of schoolchildren in Trinidad and Tobago and from diarrheic and nondiarrheic individuals in other countries $(12,13)$, and cryptosporidiosis has been responsible for epidemics of gastroenteritis in humans $(14,15)$.

Our study was conducted with the following three specific objectives: (1) to determine the prevalence of selected enteropathogens (E. coli, Salmonella spp., Shigella spp., Campylobacter spp., Cryptosporidium spp., Yersinia spp., and coccidia) in diarrheic children in Trinidad, which is one of the two islands that make up the country of Trinidad and Tobago; (2) to com- pare the frequency of detection of selected enteropathogens in diarrheal children across six counties in Trinidad; and (3) to characterize the enteropathogens isolated as to their serotypes and antibiotic sensitivity.

\section{MATERIALS AND METHODS}

\section{Hypothesis tested}

We tested the hypothesis that enteric pathogens, specifically, Salmonella, E. coli, Campylobacter spp., Yersinia spp., Cryptosporidium, and parasites are associated with childhood ( $<12$ yr) diarrhea in six counties in Trinidad. We particularly focused on two of the counties, St. George East and St. George West.

\section{Sampling protocol}

For our study, samples of feces and rectal swabs were collected from cases of childhood diarrhea in six counties: St. George East, St. George West, St. George Central, Caroni, Victoria, and St. Andrew/St. David. For St. George East and St. George West counties, samples were collected directly from their 17 health centers twice weekly over a two-year period. In addition, for all six of the counties, all specimens from childhood diarrhea submitted by health center personnel and by private practitioners to the Trinidad Public Health Laboratory during the study period were also processed. Located in the city of Port-of-Spain, the Public Health Laboratory (PHL) is a Government laboratory within the Ministry of Health. The PHL routinely 
carries out the identification of etiological agents in samples that come from the health centers and other health institutions.

In St. George West and St. George East counties, county medical officers in all the health centers (7 in St. George West and 10 in St. George East) were informed about the objectives and details of the project, and their assistance was solicited. Nurses from all 17 of those health centers were invited to meetings with the study investigators. During the meetings the researchers emphasized the invaluable contributions that the nurses could make to the success of the project, and all the nurses promised to support the study. For logistical reasons, it was decided that all cases of diarrhea in children $(<12$ yr) reported to the health centers in the two counties on Monday and Friday of each week during the study period were to be included in the study.

For the diarrheic samples from the six counties, during the study period all fecal and rectal swab samples from children $(<12$ yr) submitted by the health center personnel and private practitioners to the PHL were studied.

For the study, diarrhea was defined as the passage of three or more loose stools within $24 \mathrm{~h}$. The consent for children to participate was requested and obtained from the parents or other caregivers of the diarrheic children before any samples were collected for investigation.

\section{Collection and handling of samples}

The study was conducted from 1 April 1998 to 31 March 2000. All the study samples, either those collected directly from the 17 health centers of St. George East and St. George West counties or those from the six counties submitted directly to the PHL, were processed in the PHL, by the same individual (ZKM) and using the same protocol.

For the health centers in St. George East and St. George West counties, fecal containers and swabs in Amies transport medium were provided to personnel at each of the health centers. The nurses were requested to contact the first author (ZKM) by telephone as soon as diarrheal samples were collected from children $(<12 \mathrm{yr})$ and to keep them refrigerated. Generally, all samples were received within $4 \mathrm{~h}$ of collection, transported by the first author (ZKM) to the PHL ice-cooled, and, in most cases, processed immediately after arrival. In cases when the samples arrived late in the laboratory and could not be processed immediately, the cold chain was maintained, and processing was done within $24 \mathrm{~h}$ of collection.

\section{Isolation and identification of enteropathogens}

To detect Salmonella spp. in feces or rectal swabs, approximately $1 \mathrm{~g}$ each of fecal material on swabs was added to each of $9 \mathrm{~mL}$ of selenite cystine broth and $9 \mathrm{~mL}$ of tetrathionate broth and incubated overnight at $42{ }^{\circ} \mathrm{C}$ and $37^{\circ} \mathrm{C}$, respectively. Subcultures were made onto xylose lysine deoxycholate (XLD) agar and brilliant green agar and incubated overnight at $37{ }^{\circ} \mathrm{C}$. Typical colonies were subjected to biochemical tests and identified using standard methods (16). Polyvalent antiserum A-I and Vi was used on suspect colonies, with the slide agglutination test. Complete serological identification of Salmonella isolates was carried out at the Caribbean Epidemiology Center (CAREC), which is located in the city of Port-of-Spain, Trinidad, and serves as the Salmonella reference laboratory for the Caribbean.

For detection of Shigella spp., approximately $1 \mathrm{~g}$ of feces or fecal material on swabs was enriched in $9 \mathrm{~mL}$ of gram-negative broth for $4-6 \mathrm{~h}$ at $37^{\circ} \mathrm{C}$ and then plated on XLD agar and on MacConkey agar. Standard methods (16) were used for subsequent identification and serotyping of isolates.

To isolate E. coli, fecal or rectal swab samples were plated on eosin methylene blue agar and incubated overnight at $37^{\circ} \mathrm{C}$. Typical colonies, with greenish metallic sheen, were subjected to biochemical tests (16). Strains of E. coli that belonged to the enteropathogenic serogroups were detected by the use of polyvalent antisera A, B, and C (Difco Laboratories, Detroit, Michigan, United States) by slide agglutination tests.

Thermophilic Campylobacter spp. were detected in fecal or rectal swab samples following inoculation of blood-free Campylobacter agar with CCDA supplement (Difco, Detroit, Michigan, United States) and incubation at $42{ }^{\circ} \mathrm{C}$ in $8 \% \mathrm{CO}_{2}$ in a $\mathrm{CO}_{2}$ incubator (Forma Scientific, Marietta, Ohio, United States) for 24-48 h. Typical colonies were Gram-stained, and curved or seagull-appearing colonies were subcultured onto blood agar and subjected to the identification procedure described by Lior (17).

Yersinia spp. were isolated from samples following enrichment of $1 \mathrm{~g}$ of feces or fecal material on rectal swabs in $9 \mathrm{~mL}$ of $0.067 \mathrm{M}$ phosphate buffered saline, $\mathrm{pH} 7.6$, for three weeks at $4{ }^{\circ} \mathrm{C}$. Subcultures were made after one week and after three weeks onto Yersinia-selective medium (Oxoid, Basingstoke, United Kingdom) and incubated at room temperature for 24-48 h. Standard procedures (18) were used for biochemical identification of suspect colonies.

Gastrointestinal parasites in fecal samples were examined for coccidia and helminths using methods reported earlier (19). To detect Cryptosporidium oocysts, fecal samples were processed within $2 \mathrm{~h}$, using formalinether sedimentation techniques $(19,20)$, and subjected to microscopic examination.

For all Salmonella isolates the serotypes were determined at the CAREC.

Thermophilic Campylobacter spp. were classified into C. jejuni and C. coli, using hippurate hydrolysis (17).

To determine the antibiograms of Salmonella and Shigella isolates, the Kirby-Bauer disk diffusion method (21) was used. The following antimicrobial agents were used: ampicillin $(10 \mu \mathrm{g})$, cefotaxime $(30 \mu \mathrm{g})$, sulfamethoxazole/ trimethoprim $(1.75 / 23.75 \mu \mathrm{g})$, chloramphenicol $(30 \mu \mathrm{g})$, gentamicin $(10 \mu \mathrm{g})$, and ciprofloxacin $(5 \mu \mathrm{g})$. 
TABLE 1. Frequency of selected enteropathogens in diarrheic children by county in Trinidad, 1998-2000a

\begin{tabular}{|c|c|c|c|c|c|c|c|c|c|c|c|}
\hline \multirow[b]{3}{*}{ County/Counties } & \multirow{3}{*}{$\begin{array}{c}\text { No. of } \\
\text { samples tested }\end{array}$} & \multicolumn{10}{|c|}{ Samples positive for: } \\
\hline & & \multicolumn{2}{|c|}{ Shigellab } & \multicolumn{2}{|c|}{ Salmonella ${ }^{\mathrm{c}}$} & \multicolumn{2}{|c|}{$E P E C^{\mathrm{d}}$} & \multicolumn{2}{|c|}{ C. jejunie } & \multicolumn{2}{|c|}{ Hookworm } \\
\hline & & No. & $\%$ & No. & $\%$ & No. & $\%$ & No. & $\%$ & No. & $\%$ \\
\hline St. George East ${ }^{\dagger}$ & 60 & 12 & 20.0 & 2 & 3.3 & 1 & 1.7 & 0 & 0.0 & 1 & 1.7 \\
\hline St. George West ${ }^{\dagger}$ & 26 & 7 & 26.9 & 1 & 3.8 & 0 & 0.0 & 1 & 3.8 & 0 & 0.0 \\
\hline Six counties ${ }^{g}$ & 150 & 14 & 9.3 & 1 & 0.7 & 0 & 0.0 & 1 & 0.7 & 0 & 0.0 \\
\hline Total & 236 & 33 & 14.0 & 4 & 1.7 & 1 & 0.4 & 2 & 0.8 & 1 & 0.4 \\
\hline \multicolumn{12}{|c|}{$\begin{array}{l}\text { all samples tested were negative for Cryptosporidium spp. and Yersinia spp. } \\
\text { b The } 33 \text { positive Shigella samples consisted of } 28 \text { isolates of Sh. sonnei and } 5 \text { isolates of Sh. flexneri } 2 a \text {. } \\
\text { c The four positive Salmonella samples consisted of two isolates each of } S \text {. Typhimurium and S. Enteritidis. } \\
\text { d EPEC = Enteropathogenic Escherichia coli. } \\
\text { e C. jejuni = Campylobacter jejuni. } \\
\text { f The samples from St. George East and St. George West counties were collected directly from } 17 \text { health centers in the two counties by the researchers. } \\
\text { g The samples from six counties were submitted to the Trinidad Public Health Laboratory by health center personnel or private practitioners from the following coun- } \\
\text { ties: Caroni (108 samples), St. Andrew/St. David (3), St. George Central (20), Victoria (1), St. George East (14), and St. George West (4). }\end{array}$} \\
\hline
\end{tabular}

\section{Statistical analysis of data}

The frequency of selected enteropathogens in childhood diarrheal cases, the occurrence of serotypes, and other characteristics were compared between St. George West and St. George East counties for the specimens that had been obtained directly from their health centers. A similar comparison was made for the samples submitted to the PHL by the health center personnel and private practitioners from the six counties. The chisquare $\left(\chi^{2}\right)$ test for independence was used to analyze the data.

\section{RESULTS AND DISCUSSION}

The frequency of enteropathogens in children with diarrhea, by county studied, is shown in Table 1. A total of 86 samples were obtained directly from the 17 health centers in St. George East and St. George West counties, while 150 other samples were submitted directly to the PHL from the six counties. Overall, of the 236 fecal or rectal swab specimens studied, $33(14.0 \%)$ yielded Shigella, 4 (1.7\%) yielded Salmonella, and $1(0.4 \%)$ yielded enteropathogenic Escherichia coli (EPEC). Two $(0.8 \%)$ samples were positive for Campylobacter, and 1 $(0.4 \%)$ was positive for hookworm.
The overall frequency of enteropathogens in the diarrheic children in our study was $17.4 \%$, with assays being done for a total of seven pathogens. This figure was considerably lower than those from other studies, which ranged from $42 \%$ to $74.8 \%$ (22-24). The dissimilarity might be explained by such things as differences in the number and type of pathogens assayed for in the various studies, the handling of the specimens prior to processing, the detection procedures, and a true difference in the prevalence of the pathogens in the samples studied.

For the 86 samples collected directly from the health centers the frequency of Shigella in childhood diarrhea reported in St. George East County was $20.0 \%$ (12 of 60 ), compared with $26.9 \%$ (7 of 26) in St. George West County. However, the difference was not statistically significant $\left(\chi^{2} ; P>0.05\right)$.

Overall for the 236 samples, Sh. sonnei accounted for $28(84.8 \%)$ of the 33 Shigella isolates recovered, compared with Sh. flexneri 2a, which accounted for the other 5 Shigella isolates (15.2\%). All the 236 specimens tested were negative for Cryptosporidium and Yersinia spp.

Shigella serotypes have been documented as important etiological agents for childhood diarrhea $(23,25,26)$. Sh. sonnei, the predominant entero- pathogen detected in our study, has been associated with poor sanitary conditions $(23,25)$, and it may be an important enteropathogen in childhood diarrhea in Trinidad. Although this study was not designed to determine the etiological importance of the enteropathogens studied, Hull et al. (2) reported that Sh. sonnei was statistically significantly associated with childhood diarrhea in Trinidad $\left(\chi^{2} ; P<0.01\right)$.

In our study, Salmonella was detected in only $1.7 \%$ of the 236 fecal or swab samples from the children with diarrhea. That figure is considerably lower than the $3.9 \%$ to $19.2 \%$ reported in other studies $(26,27)$. In a study in Trinidad, Hull et al. (2) found that 7.3\% of children with diarrhea yielded Salmonella, compared with only $1 \%$ of nondiarrheic children, with the difference being statistically significant $\left(\chi^{2} ; P\right.$ $<0.05$ ). The authors concluded that Salmonella spp. were important etiological agents of diarrhea in Trinidad. The difference in the frequency of isolation of Salmonella found in our study versus the Hull et al. study (2) may reflect differences in sample size, handling of samples, methodology, and changes in pattern of infection by the pathogen over time. Salmonella serotypes are known to have caused epidemics of gastroenteritis in children and adults worldwide $(28,29)$. Salmonella enterica serotype Typhimurium (S. Typhi- 
murium) and $S$. Enteritidis have been particularly prominent in their association with Salmonella gastroenteritis in various countries, with the latter serotype being more prevalent $(11,28$, 29). Adesiyun et al. (11) demonstrated, using the pulsed-field gel electrophoresis (PFGE) technique, that $S$. Enteritidis isolates from animals in Trinidad had PFGE patterns that were similar to those for isolates from human gastroenteritis, emphasizing the zoonotic importance of this Salmonella serotype in the country. Using isolates submitted to CAREC, the same study established that the PFGE patterns of $S$. Enteritidis varied across the Caribbean, a finding that had epidemiological implications. In the Caribbean, particularly in Trinidad and Tobago, over the last decade there has been a dramatic increase in the number of cases that involved $S$. Enteritidis, based on laboratory isolation of the microorganism. Our finding that only 2 of the 236 diarrheic children $(0.8 \%)$ yielded the pathogen may be a reflection of the small sample size in our study.

The fact that only 1 of the 236 childhood diarrheic cases $(0.4 \%)$ yielded EPEC strains in our study was unexpected. These strains were isolated from $14.3 \%$ of childhood diarrheic cases in Trinidad in an earlier study (2). Also, strains of E. coli belonging to the enteropathogenic serogroups have been isolated from black pudding in Trinidad (7). In addition, frequencies of EPEC strains in childhood diarrhea of $32.7 \%$ in Brazilian children (30) and of $6.6 \%$ in Vietnamese children (31) have been reported. However, in agreement with our findings, Caprioli et al. (27) found EPEC strains to be of limited importance in Italian children.

A rather low frequency $(0.8 \%)$ of C. jejuni was found in our study, compared with $11.7 \%$ reported for hospital-reported cases in Trinidad (2). C. jejuni is an established major pathogen for gastroenteritis worldwide $(24,32,33)$.

All 236 samples processed in our study were negative for Cryptosporidium and Yersinia spp. Researchers at the CAREC have documented the detection of Cryptosporidium in apparently

TABLE 2. Frequency of isolation of enteric pathogens from childhood diarrheic cases in health centers in St. George East County and St. George West County, Trinidad, April 1998 to March 1999

\begin{tabular}{|c|c|c|c|c|}
\hline \multirow[b]{2}{*}{ Year/Month } & \multicolumn{2}{|r|}{ St. George East ${ }^{\mathrm{a}}$} & \multicolumn{2}{|c|}{ St. George West ${ }^{\mathrm{a}}$} \\
\hline & $\begin{array}{l}\text { No. of } \\
\text { samples } \\
\text { tested }\end{array}$ & No. (\%) positive for: & $\begin{array}{c}\text { No. of } \\
\text { samples } \\
\text { tested }\end{array}$ & No. (\%) positive for: \\
\hline \multicolumn{5}{|l|}{1998} \\
\hline April & 1 & 1 (100.0) - Shigella flexneri, 2a & 0 & $N A^{b}$ \\
\hline May & 5 & $\begin{array}{l}1(20.0)-\text { Sh. flexneri, } 2 a \\
1(20.0)-\text { hookworm ova }\end{array}$ & 0 & NA \\
\hline June & 14 & $\begin{array}{l}1(7.1)-\text { Sh. flexneri, 2a } \\
1(7.1)-S . \text { Typhimurium }\end{array}$ & 0 & NA \\
\hline July & 6 & $\begin{array}{c}1(16.7)-\text { EPEC }^{c} \\
1(16.7)-\text { S. Enteritidis } \\
1(16.7)-\text { Sh. sonnei }\end{array}$ & 2 & $0(0.0)$ \\
\hline August & 2 & $1(50.0)$ - Sh. sonnei & 2 & $1(50.0)$ - Sh. sonnei \\
\hline September & 5 & 1(20.0) - Sh. sonnei & 2 & 1 (50.0) - Sh. sonnei \\
\hline October & 0 & NA & 3 & 1 (33.3) - Sh. sonnei \\
\hline November & 2 & $2(100.0)-$ Sh. sonnei & 0 & NA \\
\hline December & 0 & NA & 0 & NA \\
\hline \multicolumn{5}{|l|}{1999} \\
\hline January & 0 & NA & 1 & $0(0.0)$ \\
\hline February & 1 & $0(0.0)$ & 1 & $1(100.0)-$ C. jejuni \\
\hline March & 9 & 1 (11.1) - Sh. sonnei & 3 & $0(0.0)$ \\
\hline Total & 45 & $13(28.9)$ & 14 & $4(28.6)$ \\
\hline
\end{tabular}

a These samples were collected directly from the health centers in the two counties by the researchers twice weekly (Monday and Friday) during the two-year study period.

${ }^{\mathrm{b}} \mathrm{NA}=$ not applicable since no samples were processed.

${ }^{\mathrm{C}} \mathrm{EPEC}=$ Enteropathogenic Escherichia coli.

healthy schoolchildren in Trinidad and Tobago and other Caribbean countries (CAREC, personal communication). To the best of our knowledge, no published reports exist on the involvement of Cryptosporidium in childhood diarrhea in Trinidad and Tobago, although there are reports for other Caribbean countries $(11,12)$. The parasite, which is considered a parasitic zoonosis, has been reported in livestock in Trinidad (33). The prevalence of Cryptosporidium among diarrheic children has ranged from $0.6 \%$ to $13 \%$ in different parts of the world $(15,24,34)$.

As with our study, no other published studies have reported the occurrence of Yersinia spp. in diarrhea in children or adults in Trinidad and Tobago or in other countries in the Caribbean. However, Y. enterocolitica has been isolated from livestock in Trinidad (35).

Tables 2 and 3 show the frequency of detection of enteropathogens in the
86 diarrheic cases in St. George East and St. George West by month for the periods of April 1998 to March 1999 (59 cases) and April 1999 to March 2000 (27 cases), respectively. For the two counties no seasonal difference in isolation of pathogens was detected. That contrasts with other reports that have documented seasonal variation in the involvement of enteropathogens in diarrhea $(23,28)$. The failure to find the effect of season in our study may be due, in part, to the low numbers of patients positive for enteropathogens.

For the six counties whose health centers sent the 150 fecal or rectal swabs from diarrheic children to the PHL during the two-year study period, the frequency of detection of the selected enteropathogens showed a range. For Caroni County, of a total of 108 samples submitted, 9 samples $(8.3 \%)$ were positive for the enteropathogens studied: $7 \mathrm{Sh}$. sonnei samples, 1 S. Typhimurium sample, and 1 
TABLE 3. Frequency of isolation of enteric pathogens from childhood diarrheic cases in health centers in St. George East County and St. George West County, Trinidad, April 1999 to March 2000

\begin{tabular}{|c|c|c|c|c|}
\hline \multirow[b]{2}{*}{ Year/Month } & \multicolumn{2}{|c|}{ St. George East ${ }^{\mathrm{a}}$} & \multicolumn{2}{|c|}{ St. George West ${ }^{\mathrm{a}}$} \\
\hline & $\begin{array}{l}\text { No. of } \\
\text { samples } \\
\text { tested }\end{array}$ & No. (\%) positive for: & $\begin{array}{c}\text { No. of } \\
\text { samples } \\
\text { tested }\end{array}$ & No. (\%) positive for: \\
\hline \multicolumn{5}{|l|}{1999} \\
\hline April & 6 & 1 (16.7) - Sh. sonnei & 2 & 1 (50.0) - Sh. sonnei \\
\hline May & 3 & $0(0.0)$ & 2 & $0(0.0)$ \\
\hline June & 5 & $2(40.0)$ - Sh. sonnei & 3 & $2(66.7)-$ Sh. sonnei \\
\hline July & 0 & $N A^{b}$ & 3 & 1 (33.3) - S. Enteritidis \\
\hline August & 1 & $0(0.0)$ & 0 & NA \\
\hline September & 0 & NA & 1 & $0(0.0)$ \\
\hline October & 0 & NA & 0 & NA \\
\hline November & 0 & NA & 0 & NA \\
\hline December & 0 & NA & 0 & NA \\
\hline \multicolumn{5}{|l|}{2000} \\
\hline January & 0 & NA & 1 & $1(100.0)-S h$. flexneri \\
\hline February & 0 & NA & 0 & NA \\
\hline March & 0 & NA & 0 & NA \\
\hline Total & 15 & $3(20.00)$ & 12 & $5(41.7)$ \\
\hline
\end{tabular}

a Samples were collected directly from the health centers in the two counties by the researchers twice weekly (Monday and Friday) during the two-year study period.

${ }^{b} \mathrm{NA}=$ not applicable since no samples were processed

C. jejuni sample. For St. Andrew/St. David County, 1 of the 3 samples (33.3\%) submitted was positive for an enteropathogen, for Sh. sonnei. Of the 20 samples submitted from St. George Central County, 2 (10.0\%) were positive for Sh. sonnei. The one sample received from Victoria County during the two-year study period was negative for the enteropathogens assayed. In St. George East County, of a total of 14 samples received, $3(21.4 \%)$ were positive, all being Sh. sonnei. With St. George West County, 1 of 4 samples submitted (25.0\%) contained Sh. sonnei.

During the study period, on the three days (Tuesday, Wednesday, and Thursday) each week that samples were not collected by the researchers from the 17 health centers in St. George East County and St. George West County, health center personnel submitted 14 samples and 4 samples, respectively, to the PHL for processing. For the same two-year period, with the twice-weekly sampling from the health centers in the two counties, we researchers collected 60 samples from St. George East County and 26 samples from St. George West County-that is, more than four times as many specimens. This large difference indicates that a noticeable number of fecal samples from childhood gastroenteritis cases occurring at the community level or reported to the health centers do not reach the PHL. This may be a sign that the PHL's numerical data on etiological agents associated with childhood diarrhea do not accurately reflect the degree of involvement of the various pathogens at the community level. It was noteworthy that for all the six counties together, Sh. sonnei was the predominant enteropathogen isolated, emphasizing the possible etiologic importance of the pathogen in childhood diarrhea in Trinidad.

Table 4 shows the antibiograms of the 37 Salmonella and Shigella isolates that were tested. Of the 37 isolates of Salmonella and Shigella tested for antimicrobial sensitivity, all of them were sensitive to ciprofloxacin, gentamicin, and cefotaxime. In terms of resistance, 3 of the 37 isolates $(8.1 \%)$ exhibited resistance to ampicillin, 1 $(2.7 \%)$ to chloramphenicol, and $1(2.7 \%)$ to sulfamethoxazole/trimethoprim. Of therapeutic relevance is the find- ing that Sh. sonnei, which was recovered at a much higher frequency across the counties studied as compared to the other pathogens, displayed a low level $(7.1 \%)$ of resistance to the antimicrobial agents tested. The prevalence of resistance to antimicrobial agents among the Salmonella isolates tested is considerably lower than that reported for $S$. Enteritidis isolates from the Caribbean (10).

For this investigation two major constraints or problems are obvious. One is the rather low number of reported childhood diarrheal cases at both the health center and PHL levels. The other is the low frequency of isolation of the selected enteropathogens. For the two counties (St. George East and St. George West) where samples were collected twice weekly, it was highly unlikely that only 60 samples and 26 samples, respectively, of children's diarrhea were encountered in all the health centers in the two counties over the two-year period. These low numbers for the two counties may be due in part to the fact that the personnel at the health centers were unable to report to the investigators all the diarrheal cases encountered during the two weekly sampling days, due to work pressures. In addition, with the twice-weekly collections in St. George East and St. George West counties, some health center personnel complained that some patients had difficulty in voiding feces during their visits to the centers. Those patients or their parents or guardians were given fecal containers to take home and requested to return the following day with samples of their feces, but in most instances they failed to do so. Therefore, there is evidence of underreporting of diarrhea cases in children at the health centers in those two counties.

The number of cases of childhood diarrhea reported at the health centers in the two counties visited by the first author (ZKM) was small, but the number was still considerably higher than the number of samples sent in by health center personnel and private practitioners in the six counties who delivered samples directly to the PHL. Therefore, there is clearly a need to im- 
TABLE 4. Antibiograms of 37 Shigella and Salmonella isolates recovered from childhood diarrheic cases, Trinidad, 1998-2000a

\begin{tabular}{|c|c|c|c|c|c|c|c|c|c|}
\hline \multirow[b]{3}{*}{ Pathogen ${ }^{b}$} & \multirow{3}{*}{$\begin{array}{c}\text { No. of } \\
\text { isolates tested }\end{array}$} & \multicolumn{8}{|c|}{ Isolates resistant to: } \\
\hline & & \multicolumn{2}{|c|}{ Resistant $^{c}$} & \multicolumn{2}{|c|}{$\mathrm{AMP}^{\mathrm{d}}$} & \multicolumn{2}{|c|}{$\mathrm{CHL}^{\mathrm{e}}$} & \multicolumn{2}{|c|}{$\mathrm{SXT}^{f}$} \\
\hline & & No. & $\%$ & No. & $\%$ & No. & $\%$ & No. & $\%$ \\
\hline Shigella sonnei & 28 & 2 & 7.1 & 2 & 2.7 & 0 & 0.0 & 1 & 3.6 \\
\hline Shigella flexneri & 5 & 1 & 20.0 & 1 & 20.0 & 1 & 20.0 & 0 & 0.0 \\
\hline Salmonella Typhimurium & 2 & 0 & 0.0 & 0 & 0.0 & 0 & 0.0 & 0 & 0.0 \\
\hline Salmonella Enteritidis & 2 & 0 & 0.0 & 0 & 0.0 & 0 & 0.0 & 0 & 0.0 \\
\hline Total & 37 & 3 & 8.1 & 3 & 8.1 & 1 & 2.7 & 1 & 2.7 \\
\hline
\end{tabular}

prove the diarrhea surveillance system in the country so as to ensure that samples from health centers arrive at the PHL for diagnosis.

A second issue of concern was the low frequency of the selected pathogens detected in the samples collected over the study period; $83 \%$ of the samples were negative for all the enteropathogens for which assays were done. A possible limitation was the fact that the study design was to assay for selected bacterial and parasitic pathogens only. In an earlier study of infants with gastroenteritis admitted to hospitals in Trinidad, rodue to intestinal infectious diseases in Latin America and the Caribbean, 1965-1990. Epidemiol Bull. 1991;12(3):1-6.

2. Hull BP, Spence L, Bassett D, Swanston WH, Tikasingh ES. The relative importance of rotavirus and other pathogens in the etiology of gastroenteritis in Trinidadian children. Am J Trop Med Hyg. 1982;31:142-8.

3. Pan American Health Organization. Infant mortality in the Americas. Bull Pan Am Health Organ. 1981;15(1)73-6.

4. Weissman JB, Doug Deen R, Swanston WH, Tota-Maharaj B. An island-wide epidemic of salmonellosis in Trinidad traced to contaminated powdered milk. West Indian Med J. 1977;26:135-47.

5. Trinidad and Tobago, Central Statistical Office. Population and vital statistics report. Port-of-Spain: Trinidad and Tobago, Ministry of Planning and Development; 1999. tavirus was the agent most frequently associated with the illness (2). It is possible that that viral agent may also be important in community-based childhood diarrhea in Trinidad and Tobago, and this question needs further investigation. However, in our study it is clear that Sh. sonnei was the enteropathogen most frequently isolated from the pathogen-positive fecal or rectal swab samples. We therefore conclude that Sh. sonnei may be an important etiologic agent for childhood diarrhea at the community level in Trinidad. However, a more extensive community-based cohort study is

\section{REFERENCES}

6. Karmali MA. Infection by verocytotoxinproducing Escherichia coli. Clin Microbiol Rev. 1989;2:15-38.

7. Adesiyun AA, Benjamin LA. Identification of microbial hazards, methods for their control and critical control points for black pudding ('boudin noir'). Food Microbiol. 1996;13:243-56.

8. Adesiyun AA, Webb LA, Rahaman S. Microbiological quality of raw cow's milk at collection centers in Trinidad. J Food Prot. 1995; 58:139-46.

9. Adesiyun AA, Kaminjolo JS, Loregnard R, Kitson-Piggott W. Epidemiology of Salmonella infection in Trinidadian livestock farms. Rev Elev Med Vet Pays Trop. 1993;46(3): 435-7.

10. Adesiyun AA, Campbell M, Kaminjolo JS. Prevalence of bacterial enteropathogens in pet dogs in Trinidad. Zentralbl Veterinarmed B. 1997;44(1):19-27.

11. Adesiyun A, Carson A, McAdoo K, Bailey C. Molecular analysis of Salmonella enteritidis isolates from the Caribbean by pulsed-field gel needed in order to explore the etiologic importance of this pathogen in diarrheic children in Trinidad.

Acknowledgements. We are grateful to the Caribbean Health Research Council for funding the research project. The assistance rendered by the nurses and doctors at the various county health centers is appreciated. We also appreciate the support of the Director of the Public Health Laboratory during the study. We thank the Ministry of Health for approving the project. Ms. Camille Timothy kindly typed the manuscript. electrophoresis. Rev Panam Salud Publica. 2000;8(5):342-7.

12. Macfarlane DE, Horner-Bryce J. Cryptosporidiosis in well-nourished and malnourished children. Acta Paediatr Scand. 1987;76: 474-7.

13. Kirkpatrick BD, Daniels MM, Jean SS, Pape JW, Karp C, Littenberg B, et al. Cryptosporidiosis stimulates an inflammatory intestinal response in malnourished children Italian children. J Inf Dis. 2002;186(1):94-101.

14. Isaacs D, Hunt G, Phillip A, Price G, Raafat F, Walker-Smith J. Cryptosporidiosis in immunocompetent children. J Clin Pathol. 1985; 38:76-81.

15. MacPherson DW, McQueen R. Cryptosporidiosis: multi-attribute evaluation of six diagnostic methods. J Clin Microbiol. 1993;31: 198-202.

16. MacFaddin JF. Biochemical tests for identification of medical bacteria. Baltimore: Williams \& Wilkins; 1977. 
17. Lior H. New, extended biotyping scheme for Campylobacter jejuni, Campylobacter coli, and "Campylobacter laridis." J Clin Microbiol. 1984; 20:636-40.

18. Bencovier H, Brenner DJ, Ursing J, Steigewalt AG, Fanning GR, Alonso JM, et al. Characterization of Yersinia enterocolitica sensu stricto. Curr Microbiol. 1980;4:201-6.

19. Long PL. Coccidiosis of man and domestic animals. Boca Raton: CRC Press; 1990.

20. Garcia LS, Bruckner DA, Brewer TC, Shimizu RY. Techniques for the recovery and identification of Cryptosporidium oocysts from stool specimens. J Clin Microbiol. 1993;18:185-90.

21. Bauer AW, Kirby WMM, Sherris JC, Turck M. Antibiotic susceptibility testing by a standardized single disc method. Am J Clin Path. 1966; 45:493-6.

22. Girwith, JA, Williams TW. Gastroenteritis in children: a two year review in Manitoba. I. Aetiology J Infect Dis. 1977;136:239-46.

23. Albert MJ, Faruque AS, Sack RB, Mahalanabis D. Case control study on enteropathogens associated with childhood diarrhoea in Dhaka, Bangladesh. J Clin Microbiol. 1999;37:3458-64.

24. Joyce T, McGuigan KG, Elmore-Megan M, Conroy RM. Prevalence of enteropathogens in stools of rural Masai children under five years of age in the Masailand region of the Kenyan Rift Valley. East Afr Med J. 1996;73:59-62.
25. Dutta P, Mitra U, Saha DR, Niyogi SK, Manna B, Bhattacharya SK. Mucoid presentation of acute enterocolitis in children: a hospitalbased case-control study. Acta Paedriatr. 1999; 88:822-6.

26. Youssef $M$, Shurman A, Bougnoux $M$ Rawashdeh M, Bretagne S, Strockbine M. Bacterial, viral and parasitic enteric pathogens associated with acute diarrhoea in hospitalized children from northern Jordan. FEMS Immunol Med Microbiol. 2000;28(3):257-63.

27. Caprioli A, Pezzella C, Morelli R, Giammanco A, Arista S, Crotti D, et al. Enteropathogens associated with childhood diarrhoea in Italy. The Italian Study Group on Gastrointestinal Infections. Pedriatr Inf Dis J. 1996;15(10): 876-83.

28. Checko PJ, Lewis JN, Altman R, Halpin G, Inglis R, Pierce M, et al. Multistate outbreak of Salmonella newport transmitted by pre-cooked roast beef. MMWR. 1977;26:277-8.

29. Rodrigue DC, Tauxe RV, Rowe B. International increase in Salmonella enteritidis. A pandemic? Epidemiol Infect. 1990;105:21-7.

30. Rosa AC, Mariano AT, Pereira AM, Tibana A, Gomes TA, Andrade JR. Enteropathogenicity markers in Escherichia coli isolated from infants with acute diarrhea and healthy controls in Rio de Janeiro, Brazil. J Med Microbiol. 1998;47:781-90.
31. Nguyen TV, Le Van P, Le Huy C, Gia KN, Weintraub A. Detection and characterization of diarrheagenic Escherichia coli from young children in Hanoi, Vietnam. J Clin Microbiol. 2005;43(2):755-60

32. Phetsouvanh R, Midorikawa Y, Nakamura S The seasonal variation of the microbial agents implicated in the etiology of diarrhoeal diseases among children in Lao People's Democratic Republic. South East Asia J Trop Med Public Hlth. 1999;30:319-23.

33. Kaminjolo JS, Adesiyun AA, Loregnad R, Kitson-Piggott W. Prevalence of Cryptosporidium oocysts in livestock in Trinidad. Vet Parasitol. 1993;45:209-13.

34. Assefa T, Mohammed H, Abebe A, Abebe S, Tafesse B. Cryptosporidiosis in children seen at the children's clinic of Yekatt 12 Hospital Addis Ababa. Ethiopian Med J. 1996;34:43-5.

35. Adesiyun AA, Kaminjolo IS. Prevalence and epidemiology of selected enteric pathogens of livestock in Trinidad. Prev Vet Med. 1994;19; 151-65.

Manuscript received 4 November 2003. Revised version accepted for publication 3 December 2004.
RESUMEN

\section{Frecuencia y características de ciertos enteropatógenos en especímenes fecales y rectales obtenidos de niños con diarrea en Trinidad, 1998-2000}

Palabras clave: Diarrea; infecciones bacterianas; resistencia microbiana a las drogas; Trinidad y To-

bago.

Objetivo. Determinar la frecuencia y las características de ciertos agentes enteropatógenos detectados en niños con diarrea en seis condados de la isla de Trinidad.

Métodos. El presente estudio transversal se llevó a cabo de abril de 1998 a marzo de 2000. Especímenes de heces o hisopados rectales de niños menores de 12 años se obtuvieron y se procesaron usando métodos estándarizados para la detección de Salmonella spp., Shigella spp., Escherichia coli enteropatogénico (ECEP), Campylobacter spp., Yersinia spp., Cryptosporidium paroum, y huevos de parásitos. Los antibiogramas de los agentes enteropatógenos se determinaron mediante el método de difusión en un disco.

Resultados. Se procesaron 236 muestras en total; 86 de ellas provinieron directamente de 17 centros de salud en dos condados (St. George East y St. George West), mientras que las otras 150 muestras se obtuvieron del Laboratorio de Salud Pública de Trinidad, al que fueron entregadas por médicos particulares y el personal en seis condados de la isla. De las 236 muestras, $33(14,0 \%)$ mostraron positividad a Shigella, $4(1,7 \%)$ a Salmonella, y $1(0,4 \%)$ a ECEP. Dos de las muestras $(0,8 \%)$ mostraron positividad a Campylobacter jejuni, y una $(0,4 \%)$ tenía huevos de anquilostoma. Ninguna muestra salió positiva a Cryptosporidium parvum ni a Yersinia spp. De las 86 muestras obtenidas directamente de los centros de salud, el porcentaje con Shigella fue de 20\% (12 muestras de 60) en el condado de St. George East, en comparación con 26,9\% (7 muestras de 26) en el condado de St. George West, sin que la diferencia fuese estadísticamente significativa $(P>0,05$ según la prueba de ji al cuadrado). De las 150 muestras procedentes de los seis condados que habían sido entregadas directamente al Laboratorio de Salud Pública de Trinidad, $14(9,3 \%)$ salieron positivas a Shigella. Este porcentaje fue más pequeño, en grado estadísticamente significativo, que el hallado en las muestras tomadas directamente de los centros de salud ( $P<0,05$ según la prueba de ji al cudrado). El serotipo más frecuente fue Sh. sonnei, que se observó en 28 de las $33(84,8 \%)$ cepas de Shigella aisladas de las 236 muestras. En términos generales, la frecuencia con que se detectaron enteropatógenos no varió con las estaciones del año ni mostró ninguna relación con el país de origen. Las 37 cepas de Salmonella y Shigella que se sometieron a pruebas de sensibilidad fueron sensibles en su totalidad a la ciprofloxacina, la gentamicina y la cefotaxima. Tres de las 37 cepas aisladas $(8,1 \%)$ fueron resistentes a la ampicilina, $1(2,7 \%)$ al cloramfenicol y 1 $(2,7 \%)$ a la combinación de sufametoxazol con trimetoprima.

Conclusión. De los enteropatógenos investigados mediante pruebas detectoras, Sh. sonnei fue el más frecuente y es, quizá, el principal agente causal de la diarrea infantil en Trinidad. 